University of Wollongong

Research Online

Faculty of Social Sciences - Papers (Archive) Faculty of Arts, Social Sciences \& Humanities

2016

The paradox of engagement: Land stewardship and invasive weeds in amenity landscapes

Peter Klepeis

Colgate University, pklepeis@colgate.edu

Nicholas J. Gill

University of Wollongong, ngill@uow.edu.au

Follow this and additional works at: https://ro.uow.edu.au/sspapers

Part of the Education Commons, and the Social and Behavioral Sciences Commons

Research Online is the open access institutional repository for the University of Wollongong. For further information contact the UOW Library: research-pubs@uow.edu.au 


\title{
The paradox of engagement: Land stewardship and invasive weeds in amenity landscapes
}

\begin{abstract}
In New South Wales, Australia, rural landscapes are undergoing profound change as a result of exurbanization. Newcomers-amenity migrants-are drawn to the scenic beaches, forests, and open landscape character of this part of Australia near Sydney and they join existing communities of long-term residents, notably ranchers involved in dairy, beef, and other types of primary agricultural production. The rural to exurban transition is stimulating both intended and unintended socio-ecological changes, especially the proliferation of invasive weeds, which are considered to be a top national priority as they threaten Australia's agricultural economy. Drawing on interview and survey research from three case studies in New South Wales, locations where an influx of exurbanites has led to mixed landscapes of production and consumption, we explore landowners' diverse environmental ideologies, the degree to which they collaborate with one another, and their specific land-use practices. Results show that an overwhelming majority of both exurbanites and ranchers express concerns about weeds, but there is a marked lack of coordinated engagement on invasive species between the two types of groups. This chapter is an example of social disengagement over land-use and land-cover change, rather than competition or cooperation, and contributes to a political ecological understanding of the co-construction of social relations and land management regimes.
\end{abstract}

\section{Keywords}

amenity, invasive, stewardship, land, engagement, paradox, landscapes, weeds

\section{Disciplines}

Education | Social and Behavioral Sciences

\section{Publication Details}

Klepeis, P. \& Gill, N. (2016). The paradox of engagement: Land stewardship and invasive weeds in amenity landscapes. In L. E. Taylor \& P. T. Hurley (Eds.), A Comparative Political Ecology of Exurbia: Planning, Environmental Management, and Landscape Change (pp. 221-243). Switzerland: Springer. 


\title{
Chapter 10
}

\section{The Paradox of Engagement: Land Stewardship and Invasive Weeds in Amenity Landscapes}

Peter Klepeis and Nicholas Gill

\begin{abstract}
Rural to exurban transitions stimulate both intended and unintended socioecological changes. In areas once dominated by primary producers (whom we call ranchers), newcomers represent a diversification of attitudes about nature, stewardship, land-use, and community. The attitudes and behaviours of ranchers are neither static nor homogeneous, however; both exurbanites and ranchers represent diverse environmental ideologies. The interaction between the two groups leads to a co-construction of social relations and land management regimes. The result is change not only in the social fabric of rural communities, but also in socio-ecological feedbacks, species composition, and the ecosystem services enjoyed by both exurbanites and ranchers alike. In examining shifting ideologies and shifting ecologies, we focus on the capacity to manage a key cross-boundary socio-ecological challenge: the spread of exotic invasive weeds. The Australian government ranks mitigating the negative impacts of invasive weeds as a top national priority, with rural areas experiencing in-migration representing key hotspots. Drawing on interview and survey research from New South Wales, locations where an influx of exurbanites has led to

P. Klepeis

Gill

Colgate University

Wollongong

Hamilton, NY

Australia

email: pklepeis@colgate.edu

ngill@uow.edu.au
\end{abstract}


mixed landscapes of production and consumption, we explore the perceptions landowners have of natural resources and environmental issues, the degree to which they collaborate with one another, and their specific land-use practices. Results show that an overwhelming majority of both exurbanites and ranchers express concern about weeds, but the willingness and capacity to undertake effective control measures is lacking. Also, we identify a paradox: social capital is moderately strong, ranchers and exurbanites are more similar than different, and people are involved with many community-based organizations and activities. There is a lack of coordinated engagement on invasive species among the two groups, however. Given that mitigating the negative effects of invasive weeds requires a collaborative community effort, a vital issue is to identify the mechanisms by which society can engage with those rural landowners who prefer to remain disengaged with each other.

\subsection{Introduction}

Australia is an oft-used case study highlighting land transformation. The large-scale political and economic shifts initiated by colonialism led to vast socio-ecological changes, including modifications of fire regimes, the purposeful and inadvertent introduction of exotic invasive species, and the proliferation of attitudes about nature rooted in utilitarian frameworks and capitalism (Flannery, 1994; Dunlap, 1997; Head, 2000). That landscapes of private property and production predominate in the post-colonial era suggests uniformity in ideologies of nature and land stewardship. Ideas about rural land-use are heterogeneous and evolving, however (Gill, 2014). In recent decades, rural to exurban transitions in Australia are diversifying attitudes and values among rural residents, creating a complex "management mosaic” (Epanchin-Niell et al., 
2010; Gosnell, Haggerty, \& Travis, 2006) and leading to both intended and unintended socioecological consequences (Abrams, Gosnell, Gill, \& Klepeis, 2012; Gill, Klepeis, \& Chisholm, 2010; Mendham, Curtis, \& Millar, 2012).

Amenity migration involves an influx of newcomers (exurbanites) to rural areas who do not necessarily seek to earn a living from the land but rather celebrate it for the lifestyle amenities it provides (Gosnell \& Abrams, 2011), such as "natural scenery, proximity to outdoor recreation, cultural richness, or a sense of rurality” (Abrams et al., 2012, p. 270). Landscapes once dominated by cultivated fields, extractive industries, and livestock are being transformed into areas that are multifunctional — mixed landscapes of production and consumption (Argent,

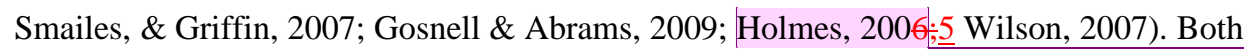
exurbanites and longtime rural residents (usually primary producers earning a living from the land and whom we call ranchers) are agents of change in these multifunctional landscapes. Each Comment [1]: in the references page this is Holmes, 2005 , not 2006. Are you referring here to a different source? If so, create an entry in the references page and omit the entry for Holmes, 2005. group represents diverse environmental ideologies and land-use goals. The interaction between ranchers and exurbanites leads to both a co-construction of social relations and also of land management regimes. Through this interaction, amenity migration is stimulating land-use and land-cover (land system) change across broad areas of Australia, Europe, North America, and parts of the Global South (Cadieux \& Hurley, 2009; Matarrita-Cascante \& Stocks, 2013).

Rural to exurban transitions result in what Breen and Hurley (2015, this volume) call “competing rural capitalisms.” The term underscores ways in which both ranchers and exurbanites seek economic change and opportunity. While much of the amenity migration literature assumes ranchers want to maintain land-use in some kind of time-honored way, ranchers often embrace modified management practices or, indeed, entirely new land-uses. Many seek regulatory and technical assistance to control weeds, mitigate wildfire risk, and maintain 
fence lines, all examples of management that facilitates primary production. But they also seek opportunities to subdivide their lands and develop real estate. Similarly, exurbanites tend to favor opportunities for new real estate markets as well, although they generally seek to develop landscapes of consumption where activities such as recreation or hobby farming are embraced. In short, in addition to areas of distinct contrast, there is often overlap between what ranchers and exurbanites value (Breen \& Hurley, this volume).

Our analysis of the socio-ecological implications of rural to exurban transitions acknowledges shifting attitudes among ranchers and exurbanites alike. Reinforcing a core argument threaded throughout this edited book, and using the example of exotic invasive weeds, we demonstrate ways in which competing rural capitalisms represent shifting ideologies and shifting ecologies. We start by reviewing how the spread of invasive plants intersects with rural to exurban transitions. We then explore notions of land stewardship, social capital, and calls within the scholarly literature for increased knowledge sharing among ranchers and exurbanites. These two sections underpin the analysis of our three case studies, which are part of a long-term study of rural change in New South Wales (NSW), Australia. Results show that both ranchers and exurbanites value privacy and do not tend to interact regularly with members of the other group. But there is significant overlap in stewardship ideology, which suggests the potential for enhanced collaboration among ranchers and exurbanites in the management of transboundary invasive weeds.

\subsection{Amenity Migration and Invasive Weeds}


The spread of exotic invasive species constitutes an important component of human-induced global environment change (Barnosky et al., 2012; Vitousek, Dantonio, Loope, Rejmanek, \& Westbrooks, 1997). During the anthropocene, in particular, the scale of exotic plant introductions has led to the creation of novel ecosystems with impacts on socio-ecological conditions and processes (Ellis, Antill, \& Kreft, 2012; McNeely, 2004; Mooney \& Cleland, 2001). Given the implications for nature and society, there have been repeated calls to investigate the human dimensions of invasive species (e.g., Ellis et al., 2012; Head \& Atchison, 2009; Robbins, 2004). In addition to climate change and the translocation of species via trade or other travel, land-use change is one of the most important factors in the introduction and spread of invasive species (Decker et al., 2012; Polce et al., 2011). For millennia people have moved plants from place to place both knowingly - even if unaware that the species is invasive - and inadvertently (Butcher \& Kelly, 2011; Crosby, 1986). In addition, as agents of landscape change people are able to create conditions favorable to invasives (Maestas, Knight, \& Gilgert, 2003; Robbins, 2004). In a prominent example, land-use change connected to amenity migration holds the potential for both the direct introduction of invasives as well as the kind of landscape preparation that makes an area vulnerable to the establishment and spread of invasive species.

Many political ecologists deem the term "invasive species" to be problematic because it privileges a particular ideology of nature or a particular relationship that one group of people has with local ecology over another (e.g., see Cadieux \& Taylor, 2012). In the context of “invasive weeds", for example, some people may champion a plant for its aesthetic value whereas others may target it for control because of perceived negative impacts on biodiversity or the land's grazing value. We acknowledge the risk in using a term that may privilege particular ideas about nature as being "right” or "appropriate”. To be clear, our use of the term invasive species 
(hereafter called "invasives") refers to the spread of plants in ways that lead to potential negative impacts on ecosystem services and primary production.

The types of consequences linked to rural change that attract the most attention from government officials and nature-society scholars are those that affect negatively ecosystem services - by which we mean the "ecosystem-based processes" that provide benefits to people, such as clean water, pollination, or recreational opportunities (Goldman, 2010) - or that present some kind of environment hazard. They tend to be cross-boundary phenomena, transcending political and ecological delineations. Issues related to wildfire (Eriksen \& Prior, 2011), forest and water resource management (Howard, 2008; Meadows, Herbohn, \& Emtage, 2012), wildlife conservation (Haggerty \& Travis, 2006), and invasives (e.g., Gosnell, Haggerty, \& Byorth, 2007; Epanchin-Niell et al., 2010) are noteworthy examples.

The actions of individual landowners vis-à-vis these cross-boundary issues affect not only their own properties but also the broader landscape (Abrams et al., 2012). If managing invasives to control their spread or intensification is the goal - although differing values may mean that it is not (Hall, 2003) - then some degree of overlap in stewardship ideology and corresponding collaboration among landowners is necessary. For example, the invasive grass serrated tussock (N. trichotoma) is on the Australian federal government's list of the country's weeds of national significance due to its degradation of pasture and negative effects on native flora (Department of the Environment, 2013). Individual serrated tussock plants can live up to 50 years and produce 100,000 seeds per year (Michelmore, 2003). Dispersed by wind up to $15 \mathrm{~km}$ seeds easily cross property boundaries. If one landowner controls the grass but her neighbor does not then the attempt, along with a considerable investment in time, money, and effort, is likely to be ineffective (Graham, 2013; Klepeis, Gill, \& Chisholm, 2009). If land productivity and 
biodiversity are not of concern, however, managing serrated tussock may be deemed unimportant.

Australia provides ample opportunity to study the intersection between invasives and rural to exurban transitions. Invasives are present in peri-urban (formerly) agricultural and rangeland areas throughout the country (Agtrans, 2005; Alam, 2012; Argent et al., 2007; Burnley \& Murphy, 2004; Williams \& West, 2000). Control of invasives is a top federal, state, and local government priority due to concerns about environmental biosecurity, which the Australian Department of the Environment (2014) defines as "the protection of the environment and social amenity from the negative effects associated with invasive species” (DPI, 2014; Kiama Municipal Council, 2014).

In our research on the towns of Windellama and Jamberoo Valley - representing inland and coastal amenity landscapes (respectively, about $234 \mathrm{~km}$ southwest and $114 \mathrm{~km}$ south of Sydney) - we interviewed both exurbanites and ranchers (Figure 3.1) (Gill et al., 2010; Klepeis et al., 2009). The research explores qualitatively the land management activities and perceptions rural landowners have of nature, invasives, and land-use. A third case study focuses on the Kiama Local Government area (LGA), and explores similar themes quantitatively using a mail survey (Gill \& Klepeis, 2011; Ikutegbe, Gill, \& Klepeis, 2014). Collectively, the three cases show the degree to which there is cross-fertilization between exurbanite and rancher ideologies concerning land-use management and measures to control invasives.

Consistent with scholarship on rural to exurban transitions elsewhere (e.g., Abrams et al., 2012), we show that exurbanites are stimulating socio-ecological shifts at landscape and property scales (e.g., fire regimes, water management, species composition of home gardens). In particular, we demonstrate changes in landowner types, stewardship attitudes and behaviors, and 
weeds management (see "Results” below). Ranchers and exurbanites have diverse attitudes about nature and society. For example, there are a plethora of reasons why individual landowners may disagree about the importance of invasives and willingness to enact control measures (e.g., Seidl \& Klepeis, 2011; Mendham et al., 2012; Moss, 2006; Tidwell \& Brunson, 2008). Some of these reasons constitute pragmatic constraints, such as absenteeism (e.g., time devoted to removal), expense (e.g., cost of herbicides), access to information and trust of the source (e.g., the capacity to identify which species are invasive), perceived efficacy of the control measures (e.g., some rural landowners see the spread of invasives as inevitable), and willingness or capacity to work collaboratively with community members. Other reasons are linked to livelihood and the nature of a person's engagement (actual and idealized) with nature, including whether or not the landowner wishes to use the land for primary production and attitudes about land stewardship (e.g., the value placed on native versus non-native plants).

Fundamentally, the Australia case studies explore how growth in the number of exurbanites affects land stewardship and the capacity to manage plants that are identified as invasives. How do exurbanite and rancher notions of what constitutes strong land stewardship differ? Do differences in how people perceive and value nature have consequences for local ecology? Are there opportunities for cooperation between groups that derive different value from the landscape? From whom do landowners seek advice? How does information flow among community members? In other words, how do rural landowners, collectively, build knowledge about local ecologies? 
Figure 3.1. Locations of study areas in New South Wales - inland (Windellama) and along the coast (Jamberoo Valley and the community of Kiama - both part of the Kiama Local Government Area) (Modified from Gill et al., 2010, p. 320)

\subsection{Stewardship, Social Capital, and Knowledge Building}

Sorice, Kreuter, Wilcox, and Fox (2014) ask whether exurbanites and ranchers are likely to have different motivations regarding land stewardship, and which group is most likely to put their ideas into practice. Defining “sound land management”, in essence, as behaviors that maintain or enhance ecosystem services, they find that exurbanites in the rangelands of central Texas are less likely to use best practices than longer-term landowners. Other case studies show a less pronounced difference in land stewardship practices between exurbanites and ranchers (e.g., Mendham et al., 2012). Our case studies show that generalizations about rural landowners and stewardship attitudes are hard to make.

Notions of land stewardship evolve (Cooke \& Lane, 2015; Gill, 2014), and community discourse in amenity landscapes create and re-craft knowledge about socio-ecological systems (Larsen \& Hutton, 2012). Emerging amenity landscapes experience dynamic change. It is reasonable to expect networks of information flow and levels of social cohesion between increasingly heterogeneous types of landowners to be in a constant state of flux. Halseth (1998) describes amenity landscapes as sites of ongoing contestation where different environmental commitments are prioritized depending on the stakeholder group in question. Similarly, Larsen and Hutton’s (2012) idea of “co-opetition” underscores ways in which stakeholders within communities experiencing amenity migration both cooperate and compete over landscape meaning (e.g., landscape of production versus consumption) and control. They note that "it is 
essential to understand not only how and why residents compete in the struggle over the landscape's form and function, but also the circumstances under which they cooperate with one another as well as with long-term residents and management professionals” (Larsen \& Hutton, 2012, p. $664 \times x)$.

An international review of research on the environmental consequences of amenity migration highlights the importance of access to information and cooperation: "the particular land-uses and activities of amenity migrants carry unique implications based, at least in part, on a lack of practical, local knowledge regarding resources and their management” (Abrams et al., 2012, p. 276). In their study of the conditions leading to cooperative forest management in Queensland Australia, Meadows et al. (2012, p. 12) note that exurbanites “require information and on-ground assistance if widespread sustainable environmental management is to be achieved.” The study demonstrates that cooperative cross-boundary forest management and control of invasives is critical in the reduction of forest fragmentation and the long-term health of forests (Meadows et al., 2012, p. 13).

Eriksen and Prior (2011, p. 617) find that both exurbanites and longtime landowners agree about the importance of knowledge sharing and community, and there are many cases of cooperation between the two groups, although fundamental challenges exist:

The high turnover of property owners in amenity-led communities can lead to an erosion of intra-community familiarity and trust, where the local knowledge concerning, for example, wildfire and wildfire preparedness is slowly lost, or held by long-term residents with little reason to share their knowledge with the 'blow-ins' (Eriksen \& Prior, 2011, p. 617) 
In addition to different “values, attitudes, knowledge, land-use, and management practices,” Mendham et al (2012) find that absenteeism inhibits the degree to which exurbanites engage with natural resource management issues. They also show that exurbanites are more likely to use the Internet whereas longtime landowners tend to interact with people via trade associations or groups such as Landcare, a government funded community-based organization that focuses on natural resource management issues.

Eriksen and Prior (2011) identify the importance of both agency-community and intracommunity efforts in building local environmental knowledge about wildfire. Their conclusion that information sharing and community problem solving is essential in mitigating wildfire points to the critical role strong social capital plays when addressing socio-ecological challenges. A community with strong social capital has networks of civic engagement that enhance social cohesion and collective problem-solving capacity. Putnam (1995, p. 67) describes social capital as "social organization such as networks, norms and social trust that facilitate coordination and cooperation for mutual benefit”. Wilson (2012, p. 5, 23) expands on the description, defining strong social capital as consisting of "networks of interaction between individuals and stakeholder groups that form a community," which are rooted in participatory and inclusive decision-making processes. He identifies social capital as one of a constellation of critical factors in a community's resilience to environmental, political and socioeconomic challenges. Often applied to social issues, such as public health, the concept of social capital has been invoked regularly in a host of nature-society studies, including investigations of society's capacity to adapt to climate change (Adger, 2003; Goulden, Adger, Allison, \& Conway, 2013; Klinenberg, 2002), natural resource development potential (Bebbington \& Perreault, 1999; Sobels, Curtis, \& Lockie,, 2001), and the strength of cooperative natural resource management arrangements

Comment [3]: In the references list this is entered as Klinenberg, 2003, not 2002. 
(Hoogesteger, 2013; Kasperson, Golding, Kasperson, 1999; Pretty \& Ward, 2001; Wagner, Kreuter, Kaiser, \& Wilkins, 2007).

The strength of social capital is relative to the ease with which knowledge flows through particular networks, a flow that social change can often disrupt. Among the factors leading to strong social capital are knowing your neighbors, the availability of skills training and education, good communication between stakeholder groups, and the ability of communities to accept change (Wilson, 2012). In contrast, weak social capital is often represented by the outmigration of young people in rural areas, a lack of leadership, mistrust of neighbors, lack of control over the destiny of the community, and poor communication between stakeholder groups (Wilson 2012, pp. 28-29).

In evaluating the level of knowledge sharing between exurbanites and ranchers we assume that if social capital is strengthened there is a greater potential for rural landowners of all types to get to know each other, build trust, identify others who are knowledgeable about regional ecology and land management, develop new norms of behavior, and develop a coordinated response to invasive weeds (Fiege, 2005; Meadows et al., 2012; Sobels et al., 2001). With differing socio-economic and cultural backgrounds, high rates of property turnover, often distinct attitudes about rural life and nature, and a high degree of absenteeism among exurbanites, however, social capital and the opportunity for knowledge sharing it provides may be weak in areas undergoing rural to exurban transitions (Klepeis et al., 2009).

\subsection{Study Areas in New South Wales}


Located in the hills of the Southern Tablelands, a region celebrated since the late $19^{\text {th }}$ century for fine wool production, the Windellama area's population grew from some 500 in 1976 to over 1,500 in 2001. Amenity migration to the area is creating a diversity of owner types and a complex mix of land-uses, including livestock production (sheep, cattle, and alpaca) and vineyards, but also a host of consumptive uses, such as recreation, rural retreat, and land investment. Large-scale subdivisions of grazing properties in the town started in the 1970s as real prices for wool declined, farm families began to seek alternative career paths, and property values began rising due to easy access to both Sydney (two-hour drive to the north) and the country's capital city, Canberra (one-hour drive to south) (Barr, Karunaratne, \& Wilkinson, 2005; Klepeis et al., 2009). In contrast to the stereotypical amenity landscape in Australia—“sea change" along the coast-Windellama is a mosaic of rangeland and woodland, representing an area of "tree change” (Figure 3.2). Six key cross-boundary socio-ecological challenges facing Windellama are wildfire, feral animals, soil erosion, dryland salinity, water scarcity, and invasive weeds.

Figure 3.2. A mosaic of rangeland and woodland in the Town of Windellama, NSW

10.4.2 Coastal "Sea Change" - Jamberoo Valley and the Kiama Local Government Area (LGA) The Kiama LGA has an area of $259 \mathrm{~km}^{2}$ and was established in 1857. On its western edge it includes a stark sandstone escarpment that runs along the coast of NSW (Figure 3.3). The central portion of the LGA contains the Jamberoo Valley, home to some 900 people. Most of the 20,906 inhabitants of the LGA live in urban centers along the Tasman Sea coast (Kiama Municipal Council, 2013). The LGA is a 30-minute drive to the city of Wollongong and a two-hour 
commute to Sydney, both to the north. The area is celebrated for its many amenities: ready access to beaches, scenic views, plentiful recreation opportunities, and proximity to popular natural features, including rainforest and waterfalls; much of the LGA presents a bucolic landscape with a mosaic of rolling hills, green pastures, forest cover, and waterways, with the escarpment as a spectacular backdrop.

In addition to its lifestyle amenities, rural parts of the Kiama LGA are valued for primary production and natural resource conservation. With high annual rainfall $(1800 \mathrm{~mm})$ and good soils, the LGA has long been an important center for dairy production (Hindle, Nott, \& Crichton, 1987). The number of dairy cattle peaked in the 1960s with the area maintaining roughly 15,000 per year during that decade. Subsequently, there has been a steady decline, with recent estimates at less than 8,000 dairy cattle (ABS, 1955-2005). Explanations for the reduction center on diminishing industry protection, low returns, and dramatically increasing land values as well as the oft-identified mix of factors leading to declines in farming elsewhere, such as shifting livelihood choices within farming families, a growth in alternative employment opportunities, and rising production costs (Edwards, 2003; Gillespie, 2003; Hindle et al., 1987; Houston, 2005; Klepeis, Scull, Lalonde, Svajlenka, \& Gill, 2013). Farmers have strong incentives to subdivide and sell their land. ${ }^{1}$ In Jamberoo Valley the percentage of the workforce in primary industry (excluding mining, but including agriculture) fell from $66 \%$ in 1976 to roughly $12 \%$ in 2001 (Gill, Chisholm, Klepeis, Wickramasuriya, \& Marthick, 2008).

\footnotetext{
${ }^{1}$ One estimate of rural land-use in the Kiama LGA finds that rural residential properties cover 6,711 ha (43.1\%), extensive agriculture covers 3,549 ha (22.8\%), and dairy operations cover 4,087 ha (26.2\%) (Sinclair, personal communication). In a country where people tend to celebrate using land "productively", the trend away from using land for dairy or agriculture and towards rural residential development contributes to debates about rural change and food security (Miller and Roots 2011).
} 
Assessments of ecosystem services in the Kiama LGA identify many endangered ecological communities, such as wetlands, subtropical rain forest, and Red Gum/Stringybark forest (Eucalyptus tereticornis, Eucalyptus eugenioides, Eucalyptus bosistoana), the latter of which is listed under Australia's Threatened Species Conservation Act of 1995 (Mills \& Associates, 2006). Other concerns are endangered flora and fauna, soil erosion, invasive species, and watershed management (Kiama Municpal Council, 2012). Among the invasive species in the LGA are 24 of those listed among Australia's 32 Weeds of National Significance-the control of which is required by law—including lantana (Lantana camera), prickly pear (Opuntia spp.), blackberry (Rubus fruticosus aggregate), and serrated tussock (Australian Government, 2013).

Figure 3.3. Jamberoo Valley, NSW, and the steep escarpment along its western edge

\subsection{Study designs}

The approaches used in the Windellama and Jamberoo Valley case studies are described in detail elsewhere (Klepeis et al., 2009; Gill et al., 2010). In brief, both projects rely primarily on semistructured, in-depth interviews with a mix of exurbanites and ranchers (totaling 36 interviews in Windellama and 25 in Jamberoo) as well as state-level regulators at the Department of Primary Industries and regional weeds officers (charged with inspecting properties and ensuring management of particular invasives as required by law). In addition, respondents owning land led walking tours of their properties during which the interview continued and observations of land management and land conditions were made. The interviews were analyzed using qualitative content analysis and 'descriptive coding', an approach that facilitates the analysis of 
words, concepts, and responses to particular questions within the broader context of the group of respondents' collective answers (Hay, 2010).

The third case study builds on the interview data to construct a survey of both ranchers and exurbanites in the Kiama LGA (Ikutegbe et al., 2014). Following standard methodology (see Dillman, Smyht, \& Christian, 2009), surveys were mailed to 1,000 households in the Kiama LGA's rural landholder database, 355 of which were returned. Consisting of 38 questions, and taking around 25 minutes to complete, the survey is split into five sections: "rural life and community”; "activities on your land”; “details about your rural property”; "prospects for the future”; and “details about you and your household.” It explores respondents' land-use and natural resource management practices, their perceptions of nature and society, indicators of different landowner types, and the strength of social capital (Table 1). Also, it includes questions requested by the Council and staff from associated bodies, such as the Illawarra District Noxious Weeds Authority, the Small Farms Network, and the Department of Primary Industries.

The extent to which land_--based income is important to landowners - reflecting their “production or consumption orientation” (Mendham et al., 2012) - is an oft-used point of difference between exurbanites and ranchers (Abrams et al., 2012). The mail survey gathers data on whether land provides primary, significant secondary, minor, or no income. Here, to simplify the analysis, we collapse these four categories into two groups - those who derive a primary or significant secondary income from land (50 respondents who we call ranchers) and those who derive minor or no income from their land (288 respondents who we identify as exurbanites). Overall, $21 \%$ of respondents own 0.4 ha or less, $86 \%$ own 40 ha or less, and $4 \%$ own 100 ha or more: the average landholding is 22 ha and the maximum is 400 ha. 
Using in-depth and semi-structured interviews in early phases of the research and then generating formal surveys to test hypotheses generated by the earlier qualitative work is highly effective at identifying both context-specific dynamics as well as general trends in the study areas. The main weakness in our approach is that we do not assess ecological conditions directly; that is, ideally, our team would measure ecological conditions at the same properties where we conducted our interviews. Such an ecological assessment would allow us to connect specific ideologies about nature with particular land management strategies and their impacts on local ecology. Instead, our research uses interview and survey data to document land management impacts. 


\begin{tabular}{|c|c|c|}
\hline & Question & Summary Result \\
\hline 1. & $\begin{array}{l}\text { Have you attended a local community } \\
\text { event in the Kiama LGA in the past six } \\
\text { months (such as a church or school event, } \\
\text { craft exhibition, bushcare project)? }\end{array}$ & $\begin{array}{l}\text { The large majority ( } 77.7 \%) \text { have attended at least one community event in the last six } \\
\text { months. There is not much variation between exurbanite and rancher groups. }\end{array}$ \\
\hline 2. & $\begin{array}{l}\text { Have you visited a neighbor's home in the } \\
\text { past week? }\end{array}$ & $\begin{array}{l}57.2 \% \text { have visited a neighbor at least once in the past week. A large portion }(42.7 \%) \\
\text { reported no visits in the past week while } 25.2 \% \text { have visited two times or more. There is } \\
\text { not much variation between exurbanite and rancher groups. }\end{array}$ \\
\hline 3. & $\begin{array}{l}\text { How often do you do volunteer work for a } \\
\text { local group or club? }\end{array}$ & $\begin{array}{l}45.1 \% \text { volunteer for a local group or club once a month or more. Roughly one-third of } \\
\text { respondents never partake in this activity while one-quarter report volunteering rarely. } \\
\text { There is not much variation between exurbanite and rancher groups. }\end{array}$ \\
\hline 4. & $\begin{array}{l}\text { Owning rural land in the Kiama LGA has } \\
\text { brought me into contact with types of } \\
\text { people with whom I have not interacted } \\
\text { before. }\end{array}$ & $\begin{array}{l}59.9 \% \text { have had contact with types of people with whom they had not interacted before. } \\
\text { There is not much variation between exurbanite and rancher groups. }\end{array}$ \\
\hline 5.1 & $\begin{array}{l}\text { Do you work with other people in } \\
\text { managing your land? }\end{array}$ & $\begin{array}{l}\text { A small majority }(53.3 \%) \text { work with other people in managing their land. A great deal } \\
\text { more ranchers }(78 \%) \text { work with people in managing their land than exurbanites } \\
(49.5 \%) \text {. }\end{array}$ \\
\hline 5.2 & $\begin{array}{l}\text { If yes (to question } 5.1 \text { ) then with whom } \\
\text { have you had significant contact? }\end{array}$ & $\begin{array}{l}\text { Overall, neighbors, friends, and family are the largest groups landowners have contact } \\
\text { with in managing their land, followed by contractors. Exurbanites rely much more on } \\
\text { neighbors and contractors than ranchers. }\end{array}$ \\
\hline
\end{tabular}

Table 1. Questions indicating the strength of social capital within the Kiama Local Government

Area and key results. 


\subsection{Results}

In addition to fulltime ranchers, the study areas include both fulltime and part-time exurbanites (i.e., occasional visitors or absentee landowners who have secondary residences elsewhere or who own rural real estate for investment purposes). Approximately 65\% of Windellama’s exurbanites are part-time. In the Kiama LGA - a site of dynamic demographic change - there is a high level of absenteeism with some 28\% of rural landowners spending only an average of 24 weeks per year on their property. In addition, the frequency of land transfers is high: $58 \%$ of ranchers are likely to sell their land in the next five years due to "council rates," "burden of maintaining the property," and agricultural viability. And $40 \%$ of exurbanite respondents plan to sell within the same period because of age, health, and the "burden of maintaining the property."

Fulltime exurbanites in all three study areas tend to be either commuters or retirees whose main or only source of income is off-farm, although some seek to generate profit from hobby farming. Two thirds of exurbanites in Jamberoo Valley, for example, raise livestock on either a commercial or semi-commercial basis. But even for exurbanites with significant land_--based businesses, the income is usually secondary to that provided by investments or jobs elsewhere.

\subsubsection{Stewardship Attitudes and Land Management}

Overall, ideology about nature and land stewardship among exurbanites and ranchers is surprisingly similar when described in general terms (Table 2). In all three study areas, most rural landowners see themselves as stewards of the land. The overwhelming majority of both exurbanites and ranchers advocate for active land management to address fire hazards, soil erosion, water management, and invasives. That there is consensus about conserving land and water resources is not surprising given that these issues receive a tremendous amount of attention 
in Australia both in the popular press and scholarly literature. Also, most ranchers and exurbanites advocate for some kind of "productive” use of the land by which they mean production of food, fiber, or timber.

Not surprisingly, ranchers identify "making a living” as the main reason they own land, followed by family connections and land as an investment: 15\% of survey respondents identify production on their land as the primary or secondary source of income. Sixty-six percent of those surveyed, in contrast, generate no income from their land. But a common value both to ranchers who use the land to earn a living (usually relying significantly on off-farm income as well) and exurbanites is a desire to reside in "rural nature." Exurbanites, in particular, value the opportunity to experience wildlife and natural amenities while learning about the importance of rural production and agriculture. They also seek seclusion and the capacity to have complete control over what they do with their land, an attitude that may inhibit involvement with communitybased natural resource management groups. Exurbanites identify "lifestyle” followed by "being closer to nature” as their primary reasons for owning land.

Dairy is the most significant production activity for ranchers in the Kiama LGA (average production value in 2008-09, AU\$143,100), distantly followed by beef (average production value in 2008-09, AU\$9,650). For exurbanites who dabble with hobby farming beef production is the most significant activity with an average production value of AU\$1,397. Exurbanites are more likely to use their land as a retreat or for conservation. Beyond the obvious time difference spent on pasture maintenance, responses to a question about the number of days respondents spent on specific activities in the last year expose additional differences, including choices about recreation (e.g., hunting versus horseback riding) (Table 3). 
What seems to be a common ideology about nature—maintaining "productive" land— breaks down when specific management options are considered. The weight placed on maintaining land productivity compared to maintaining or promoting habitat for native species varies, for example. One exurbanite felt he was helping to "win nature back" by removing invasives and planting native species, but also through grazing cattle; he sees a mix of ecological restoration and food production as the right kind of "nature." Surprisingly, given the general emphasis on improving ecological conditions, exurbanites in the Kiama LGA outperform ranchers in only one (undertaking a flora and fauna assessment) out of 14 actions that represent elements of sound natural resource management (Table 3).

\begin{tabular}{|l|l|l|}
\hline \multicolumn{1}{|c|}{$\begin{array}{c}\text { Stewardship } \\
\text { Type }\end{array}$} & \multicolumn{1}{|c|}{ Description } & \multicolumn{1}{c|}{ Examples of Priorities } \\
\hline Lifestyle Agrarian & $\begin{array}{l}\text { Akin to traditional rural or farming } \\
\text { senses of stewardship: primary } \\
\text { production and conservation are } \\
\text { seen as compatible and a pragmatic } \\
\text { part of land management. }\end{array}$ & $\begin{array}{l}\text { Focus on animal husbandry. } \\
\text { Fencing of existing native } \\
\text { vegetation and riparian } \\
\text { protection. Plantings of natives } \\
\text { and non-natives, but local } \\
\text { species not a priority. }\end{array}$ \\
\hline Regenerative & $\begin{array}{l}\text { Interest in improving land } \\
\text { management as a whole with } \\
\text { improved ecological management } \\
\text { and restoration as important goals. } \\
\text { Production goals are often present } \\
\text { but they may be equivalent or } \\
\text { subservient to conservation goals. }\end{array}$ & $\begin{array}{l}\text { Significant efforts at replanting } \\
\text { or restoration of native } \\
\text { vegetation. Extensive weeding. } \\
\text { Semi-commercial grazing, } \\
\text { cropping, or horticulture. } \\
\text { Limited pasture management } \\
\text { focused on herd size and } \\
\text { slashing. }\end{array}$ \\
\hline Conservationist & $\begin{array}{l}\text { Primary focus is on ecological } \\
\text { restoration and provision of habitat. } \\
\text { Agricultural land-use is perceived as } \\
\text { having had largely negative } \\
\text { consequences, some of which are } \\
\text { ongoing, and exurbanite ownership } \\
\text { is seen as an opportunity to remedy } \\
\text { past mistakes even if in a small way. }\end{array}$ & $\begin{array}{l}\text { Extensive efforts at replanting } \\
\text { or restoration of native } \\
\text { vegetation. Extensive weeding. } \\
\text { Local species usually preferred } \\
\text { but "Australian natives" or } \\
\text { non-natives may meet their } \\
\text { aims. No stock or only small } \\
\text { numbers of "recreational" } \\
\text { animals. }\end{array}$ \\
\hline
\end{tabular}


Table 2: Forms of stewardship among exurbanites (after Gill et al., 2010, p. 30)

With respect to invasives, ranchers place much greater emphasis on controlling pasture weeds and feral animals that might attack livestock or dig-up pastures. Exurbanites tend to support aggressive control measures, but they are, for the most part, ill-informed about invasives; in one example, an exurbanite in Windellama went so far as to plant the invasive grass serrated tussock in his garden because he thought erroneously that it was a native species and that it looked nice; he planted it despite the fact that he is in favor of controlling invasives. Other factors standing in the way of effective, landscape-scale management are time (exurbanites and ranchers alike do not want to, as one rancher put it, "spend their lives chasing tussocks"), money, and effort, but also social barriers to exurbanite and rancher interaction. For example, $90 \%$ of exurbanites and $82 \%$ of ranchers said "privacy" is one of their reasons for owning land. And many primary producers see exurbanites as interlopers or uneducated (about rural living and land management) city dwellers “invading” rural landscapes.

\begin{tabular}{|l|c|c|c|c|}
\hline Actions taken on property in the past three years & \multicolumn{2}{|c|}{$\begin{array}{c}\text { Ranchers } \\
\text { (n=50) }\end{array}$} & \multicolumn{2}{c|}{$\begin{array}{c}\text { Exurbanites } \\
\text { (n=288) }\end{array}$} \\
\hline & Number & $\%$ & Number & $\%$ \\
\hline Soil testing for nutrient monitoring/application & 20 & 40.0 & 52 & 18.1 \\
\hline Cooperative land-use or management with neighbors & 12 & 24.0 & 47 & 16.3 \\
\hline Weed management with a group or organization & 12 & 24.0 & 45 & 15.6 \\
\hline Feral animal control with a group or organization & 25 & 50.0 & 18 & 6.3 \\
\hline $\begin{array}{l}\text { Reduced native vegetation cover including } \\
\text { understory, by any means }\end{array}$ & 3 & 6.0 & 18 & 6.3 \\
\hline $\begin{array}{l}\text { Considered or have changed land-use/management } \\
\text { due to climate change }\end{array}$ & 9 & 18.0 & 17 & 5.9 \\
\hline
\end{tabular}




\begin{tabular}{|l|c|c|c|r|}
\hline Tried to control/prevent soil erosion & 15 & 30.0 & 60 & 20.8 \\
\hline Water quality testing & 11 & 22.0 & 24 & 8.3 \\
\hline Planted non-native vegetation outside the garden & 5 & 10.0 & 31 & 10.8 \\
\hline Weed management undertaken privately & 35 & 70.0 & 56 & 19.4 \\
\hline Feral animal control undertaken privately & 18 & 36.0 & 56 & 19.4 \\
\hline $\begin{array}{l}\text { Received/spent grant money on environmental or } \\
\text { agricultural projects }\end{array}$ & 10 & 20.0 & 23 & 8.0 \\
\hline $\begin{array}{l}\text { Implementation of ideas/techniques gained from a } \\
\text { course/field day/training program }\end{array}$ & 11 & 22.0 & 34 & 11.8 \\
\hline Undertaken a flora and fauna assessment & 4 & 8.0 & 28 & 19.7 \\
\hline
\end{tabular}

Table 3. The number of ranchers and exurbanites who have taken particular actions on their properties in the past three years (note that two of the actions listed in the figure - reducing native vegetation cover and planting non-native vegetation outside of the garden - represent poor management as defined by Australian government agencies whereas the rest of the actions contribute to strong land management).

Ranchers might be more knowledgeable than exurbanites, but often do no better when managing invasives. Most exurbanites do not manage invasives effectively, which breeds a sense of fatalism about the spread of weeds among ranchers and they often do not implement effective weeds control measures despite the negative impact on land productivity. Around 91\% of rural landowners in the Kiama LGA survey undertake activities to control weeds, although ranchers spend 52.6 days per year weeding when compared to an average of 22.4 by exurbanites (Table 4). The seemingly greater emphasis on weeding by ranchers is turned on its head, however, when considering weeding intensity. Alam (2012) demonstrates that exurbanites in the study area spending much more time on weeds management per hectare (15 days/ha/yr) compared to 
ranchers (1 day/ha/yr). Seventy-five percent of ranchers answer "no" to a question about whether they spend as much time on controlling weeds as they would like compared to $56 \%$ of exurbanites. In general, despite a shared concern about weeds, the plants of concern to exurbanites in the Kiama LGA, such as fireweed (Senecio madagascariensis) and lantana, appear to reflect a greater concern with plants that are problems for conservation as compared to those affecting pasture. Time constraint is the main limiting factor in weed control effort: financial resources, age, health, and a perception that the weed problem is overwhelming are secondary factors.

In sum, while there is broad consensus within Jamberoo that invasives are to be controlled, the degree to which that desire translates into action is mixed:

Most interviewees were not actively managing for restoration or regeneration of native vegetation, although most were interested in protecting vegetation on their land. Some were effectively maintaining the property as they found it, for example by slashing at the margins of native vegetation to maintain pasture and control invasive plants. Thus in most cases, vegetation management consisted of sympathetic or benign neglect. (Gill et al., 2010, p. 326)

Benign neglect, in the case of invasives, is insufficient to address the challenge. While some exurbanites commit significant time and money to managing vegetation, their activities are neither strategic nor collaborative. Knowledge-building through interacting with other stakeholders in the community might aid exurbanites in Jamberoo in realizing some of their land management goals, but a desire to be private and withdraw from society, to some degree, stands in the way. 


\subsubsection{The Potential for Collaboration}

Exurbanites and ranchers tend to run in different social circles. It is the predominance of these social divisions that lead us to hypothesize that social capital in amenity landscapes is weak. Ranchers are more likely to participate in the fire brigade, for example, and knowledge about wildfire among exurbanites is poor (Eriksen \& Gill, 2010). Exurbanites are also less likely than ranchers to be willing to receive training on the application of weeds-killing chemicals and they are less likely to maintain fence lines that border property. In addition, exurbanites are more likely to be part-time residents of their rural properties and they tend to have less skills training and education about natural resource management, both factors affecting negatively the social capital of the study area.

Most people are involved with multiple community-based organizations and activities; however, there is a degree of social separation between the different landowner types. In addition, a moderate level of social capital is reflected in whom people trust for information about land management. Ranchers are more likely than exurbanites to consult friends and family regarding natural resource management. While also seeking advice from friends and family, exurbanites tend to seek more input from neighbors and contractors than ranchers do (Ikutegbe et al., 2014, p. 9).

Despite our assumption going into the research that social capital would be weak, however, its strength is higher than expected: the networks of interaction (see Wilson, 2012) in which exurbanites and ranchers participate do overlap, although only partially. As reported in Ikutegbe et al. (2014) networks of communication and interaction seem to differ depending on whether the landowner emphasizes amenity-oriented land-use or seeks significant income from the land. Due to high turnover rates among property owners and high rates of absenteeism - both 
of which inhibit the capacity to interact with other community members (Mendham et al., 2012; Klepeis et al., 2009) - exurbanites tend to acquire more information from the Internet, nurseries, and representatives from professional agencies than neighbors and other community members. The community members with whom they do interact tend to be other exurbanites and not necessarily those landowners with the greatest local environmental knowledge. The Kiama LGA survey data show that exurbanites and ranchers differ in whom they considered the most important contact in managing land. Primary or significant secondary income producers are significantly more likely to consider family and friends the most important contact in managing their land, where exurbanites were more in contact with neighbors and contractors as well as friends and family (Gill \& Klepeis, 2011).

\begin{tabular}{|c|c|c|c|c|}
\hline \multicolumn{5}{|c|}{ Average time spent on activities in the past year (full days) } \\
\hline & $\begin{array}{l}\text { Number of } \\
\text { Exurbanites } \\
\quad(n=288)\end{array}$ & $\begin{array}{l}\text { Days } \\
\text { (Mean) }\end{array}$ & $\begin{array}{l}\text { Number of } \\
\text { Ranchers } \\
(n=50)\end{array}$ & $\begin{array}{l}\text { Days } \\
\text { (Mean) }\end{array}$ \\
\hline Improving soil/fertilizing/planting legumes & 70 & 15.2 & 22 & 72.1 \\
\hline Weeding/weed management & 166 & 22.4 & 30 & 52.6 \\
\hline Pasture maintenance & 136 & 26.0 & 33 & 93.8 \\
\hline Walking/bushwalking & 63 & 26.7 & 6 & 6.7 \\
\hline Planting in the garden & 288 & 3.7 & 50 & 9.7 \\
\hline $\begin{array}{l}\text { Planting native trees/plants outside of the } \\
\text { garden }\end{array}$ & 288 & 3.7 & 50 & 2.4 \\
\hline Planting perennial pasture & 23 & 3.4 & 12 & 31.7 \\
\hline Motor biking & 15 & 9.9 & 6 & 120.7 \\
\hline Horse riding & 14 & 68.2 & 3 & 67 \\
\hline Hunting & 6 & 19.0 & 5 & 74.8 \\
\hline
\end{tabular}




\begin{tabular}{|l|r|r|r|r|}
\hline Other & 24 & 6.3 & 6 & 90.5 \\
\hline
\end{tabular}

Table 4. The number of respondents undertaking specific activities in the past year and the average number of full days they spent on the activity..

While knowledge about an environmental issue is not the only or even the most important factor in explaining whether people adopt practices that mitigate a particular problem (e.g., Guagnano, Stern, \& Dietz, 1995; McCaffrey, 2004; MacNaghten \& Urry, 1998; Robbins, 2007), access to information and technical advice on land management is a vital element in the mix. Ranchers are more likely than exurbanites to seek expert advice regarding their rural property, although only $34 \%$ are likely to seek advice before planting noncommercial trees compared to $55 \%$ of exurbanites. The most important sources of advice for tree planting by exurbanites are books, magazines, the Internet, and nurseries: ranchers consult those sources as well, but place additional emphasis on advice from experts within natural resource management groups such as Landcare and the Southern Rivers Catchment Authority. Ranchers are much more likely than exurbanites to have cooperated about land-use management with neighbors, weed management with a group organization, and feral animal control with a group organization (Table 3). That said, only $24 \%$ of ranchers undertook cooperative land management, a relatively low percentage if cross boundary socio-ecological problems are to be managed effectively. Ranchers are almost twice as likely to participate in field days and training programs. Overall, ranchers tend to be more engaged on natural resource management issues and tend to reflect stronger social capital then exurbanite groups, although cooperative behaviors are undertaken by a relatively small number of people in both categories. 


\subsection{Shifting socio-ecologies}

Throughout our research we have assumed that rural to exurban transitions will stimulate change in knowledge about flora, notions of stewardship, and how people learn about nature. Our assumption has been proven correct. Despite a moderate level of social capital as reflected by attendance at events, visits to neighbors, and community volunteer work, both exurbanites and ranchers value their privacy and tend to avoid significant collaboration on natural resource management. A lack of time is the primary reason identified by landowners for the minimal collaboration between the two groups, although absenteeism and cultural differences and traditions are important as well, such as the value placed on volunteering for the fire brigade or attitudes towards hunting, motor biking, and other recreational activities.

Exurbanites and ranchers may not cooperate with one another often, but there are elements of overlap in notions of stewardship. Opportunities exist for enhanced cooperation among them (Larsen, Foulkes, Sorenson, \& Thompson, 2011). Both rely on similar sources of information and advice, and both groups are worried about invasive weeds (Ikutegbe et al., 2014). Also, the desire for knowledge building and access to advice seems to be strong in both cases. A majority of rural landowners are engaged with other community members in one way or another, and it is reasonable to assume that some kind of cooperation on land management might result. But there is a paradox: despite moderate intra-community engagement on natural resource management, landowners are largely disconnected on management of invasives.

We assume that the role of government should be to reduce environmental harms and encourage environmental benefits (which we define using the concept of ecosystem services). One pathway for the government is to improve the exchange of environmental knowledge among 
all rural stakeholders. We acknowledge that creating or enhancing social capital through public policy is inherently challenging (Ballet et al., 2007), but given that addressing the spread of invasive weeds requires landscape scale, multi-stakeholder collaborative action, it follows that natural resource management experts need to help strengthen social capital in amenity landscapes to the degree possible.

In their study of “co-opetition”, Larsen and Hutton (2012, p. xx664) conclude that Comment [5]:

“periodic and sometimes intense interdependence and mutual aid” may create opportunities for dialogue that are sensitive to distinct ideologies about nature and landscape orientations. A critical issue is to identify the mechanisms by which community members or government officials can engage with those rural landowners who prefer to remain disengaged with each other. These opportunities may be found in key areas of consensus, such as water management and mitigating soil erosion. And given that almost all landowners are concerned about invasives, even if for different reasons, then dialogue about other issues may spill over into discussion of weeds management.

We suggest that exurbanites would benefit from greater interaction with ranchers, and more direct contact with professional natural resource managers, such as weeds inspectors. Currently, the fines for poor invasive weeds management are quite small, and do not serve as a stimulus for rural landowners to manage weeds effectively. One policy response is to make the fines larger. But our work on social capital and information flow suggests that government officials might serve as catalysts for creating dialogue across rural landowner type. For example, weeds inspectors might organize neighborhood seminars and workshops regarding a number of issues, including those related to water, soil, and weeds. In other words, officials can create a 
host of topics that will attract a broader audience and construct a workshop format that allows for neighbors to interact directly with one another.

Graham (2013) identifies a second pathway to control the invasive weed serrated tussock, which involves enhancing information flow by building relationships among neighbors. In particular, she notes that the collaborative, community-based conservation group Landcare represents a mechanism through which different landowner types might build relationships, strengthen social capital, and work towards more effective collective weed management. The use of existing institutions, such as Landcare, is consistent with our finding that networks of information flow that cross landowner type are already present in many community landscapes.

\subsection{Conclusions}

The Australia case studies connect the behaviours, motivations, ideologies, and socio-economic relations among rural actors to particular types of land management. We use the example of invasive weeds as an important window into how 'competing rural capitalisms' play out in amenity landscapes. The economic relation to land of different owners is important in how they know, perceive, and act on weeds (e.g., which ones they worry about, if they worry at all). And the degree of co-opetition among ranchers and exurbanites affects the landscape ecologies that develop, including patterns of land-use and weed distribution. The issue of invasives highlights tension between people celebrating collective interests, such as managing an important transboundary socio-ecological challenge, and those generated by private property rights under capitalism (reflected by some who want isolation and privacy).

The issue of invasive weeds also presents a window into the aspirations and value for nature held by landowners, perhaps most interestingly the exurbanites. The way people manage 
weeds and the broader activities within which weeding exists (e.g., bush restoration) reflects the kind of nature they want to create. Apart from any influence exurbanites might have, most significant changes in amenity landscapes have come about through passive land management and the retreat of agriculture - steep slopes are abandoned, woody vegetation recovers, and invasives spread (Klepeis et al., 2013). In contrast, exurbanites bring an active and intentional agency to rural land management through activities such as weeding, native plant restoration, and efforts to promote forest recovery. We have observed in Jamberoo Valley, for example, exurbanites removing the invasive Lantana camera from forests on a scale a rancher would never do, simply because most ranchers do not have the time and money to do so.

To the degree that there is more intense land management per hectare by exurbanites compared to ranchers - and given that exurbanites and ranchers tend to focus on different types of invasives - our results suggest the possibility of an enhanced capacity to control invasives in the future. Many exurbanites express more interest in conservation than ranchers; however, they often lack the skills, knowledge, and time to implement land management that reflects their expressed values. As the rural to exurban transition matures, the number of exurbanites goes up, and the new skills and knowledge exurbanites have about invasives and land management grows, there are likely to be even greater attempts by exurbanites to assert their agency. The result may be even more pronounced shifts in ideologies and ecologies than those observed to date. 


\section{References}

Abrams, J., Gosnell, H., Gill, N., \& Klepeis, P. (2012). Re-creating the rural, reconstructing nature: An international literature review of the environmental implications of amenity migration. Conservation and Society, 10(3), 270-284. doi: 10.4103/0972-4923.101837

ABS (Australian Bureau of Statistics) 1954/55-2005/6. Agricultural Censuses. Retrieved from http://www.abs.gov.au/websitedbs/c311215.nsf/web/agriculture+-+agricultural+census.

Adger, N.W. (2003). Social capital, collective action, and adaptation to climate change.

Economic Geography 79(4), 387-404. doi: 10.1111/j.1944-8287.2003.tb00220.x

Agtrans (2005). Review of the progress on invasive species. Final report to Department of

Environment and Heritage. Agtrans research in conjunction with Noel Dawson, Brisbane, 142 pp. Retrieved from

http://deh.gov.au/biodiversity/invasive/publications/review/index.html

Alam, M.J. (2012). Invasive plant management in complex social landscapes: A case study in coastal New South Wales in Australia (Unpublished master's thesis). School of Earth and Environmental Science, University of Wollongong.

Argent, N., Smailes, P., \& Griffin, T. (2007). The amenity complex: Towards a framework for analyzing and predicting the emergence of a multifunctional countryside in Australia. Geographical Research, 45(3), 217-232. doi: 10.1111/j.1745-5871.2007.00456.x

Australian Department of the Environment. (2014). Invasive Species. Retrieved from http://www.environment.gov.au/biodiversity/invasive-species

Barr, N., Karunaratne, K., Wilkinson, R. (2005). Australia’s farmers: Past, present and future. Canberra, Australia: Land \& Water Australia. 
Bebbington, A., \& Perreault, T. (1999). Social capital, development, and access to resources in highland Ecuador. Economic Geography, 75(4), 395-418. doi: 10.1111/j.19448287.1999.tb00127.x

Burnley, I., Murphy, P. (2004). Sea change: Movement from metropolitan to arcadian Australia. Sydeney: University of New South Wales Press.

Butcher, E.R., \& Kelly, D. (2011). Physical and anthropogenic factors predict distribution of the invasive weed Tradescantia fluminensis. Austral Ecology, 36, 621-627. doi: 10.1111/ j.1442-9993.2010.02196.x

Cadieux, K.V. \& Hurley, P. (2011). Amenity migration, exurbia, and emerging rural landscapes: global natural amenity as place and as process. GeoJournal, 76(4), 297-302. doi: 10.1007/s10708-009-9335-0

Cadieux, K.V., \& Taylor, L. (Eds). (2012). Landscape and the ideology of nature: Green sprawl. London: Routledge.

Cooke, B., \& Lane, R. (2015). How do amenity migrants learn to be environmental stewards of rural landscapes? Landscape and Urban Planning, 134, 43-52. doi:10.1016/j.landurbplan. 2014.10.006

Crosby, A.W. (1986). Biological Imperialism: the biological expansion of Europe, 900-1900. New York: Cambridge University Press.

Decker, K.L., Allen, C.R., Acosta, L., Hellman, M.L., Jorgensen, C.F., Stutzman, R.J., . . \& \& Yans, M. (2012). Land use, landscapes, and biological invasions. Invasive plant science and management, 5(1), 108-116. doi:10.1614/IPSM-D-11-00007.1

Department of the Environment. (2013). Weeds of National Significance. Australian Government. Retrieved from 
http://www.environment.gov.au/biodiversity/invasive/weeds/weeds/lists/wons.html

Dunlap, T.R. (1997). Australian nature, European culture: Anglo settlers in Australia. In Miller, C., \& Rothman, H. (Eds.), Out of the woods: Essays in environmental history (pp. 273-289). University of Pittsburgh Press.

DPI (Department of Primary Industries). (2014). Biosecurity. Retrieved from http://www.dpi.nsw.gov.au/agriculture/pests-weeds/weeds/definition

Dillman, D. A., Smyht, J. D., \& Christian, L. M. (2009). Internet, mail and mixed-mode surveys: The tailored design method. New York: Wiley.

Edwards, G. (2003). The story of deregulation in the dairy industry. The Australian Journal of Agricultural and Resource Economics, 47, 75-98.

Ellis, E.C., Antill, E.C., Kreft, H. (2012). All is not loss: Plant biodiversity in the anthropocene. PLoS ONE, 7(1), e30535. doi: 10.1371/journal.pone.0030535

Epanchin-Niell, R. S., Hufford, M. B., Aslan, C. E., Sexton, J. P., Port, J. D., \& Waring, T. M. (2010). Controlling invasive species in complex social landscapes. Frontiers in Ecology and the Environment, 8(4), 210-216. doi: 10.1890/090029

Eriksen, C. \& Gill, N. (2010). Bushfire and everyday life: examining the awareness-action 'gap' in changing rural landscapes, Geoforum, 41, 814-825. doi:10.1016/j.geoforum.2010.05.004

Eriksen, C., \& Prior, T. (2011). The art of learning: Wildfire, amenity migration and local environmental knowledge. International Journal of Wildland Fire, 20(4), 612-

624. doi:

10.1071/WF10018 
Fiege, M. (2005). The weedy West: Mobile nature, boundaries, and common space in the Montana landscape. The Western Historical Quarterly, 36(1), 22-47. doi: $10.2307 / 25443100$

Flannery, Tim. (1994). The future eaters: An ecological history of the Australasian lands and People. New York: Grove Press.

Gill, N. (2014). Making country good: Environmental change and stewardship in central Australian pastoral culture. Transactions of the Institute of British Geographers, 39(2), 265-277. doi: 10.1111/tran.12025

Gill, N., \& Klepeis, P. (2011). Data Summary: Living, Working, and Playing on the Land Survey. $\quad$ Retrieved from http://socialsciences.uow.edu.au/ausccer/UOW002998.html

Gill, N., Klepeis, P., \& Chisholm, L. (2010). Stewardship among lifestyle oriented rural landowners. Journal of Environmental Planning and Management, 53(3), 317-334. doi: $10.1080 / 09640561003612890$

Gill N., Chisholm, L., Klepeis, P., Wickramasuriya, D.R., Marthick, J. (2008). Land management and land cover on land owned by amenity oriented rural landowners in Jamberoo Valley. $\quad$ Retrieved from http://ro.uow.edu.au/scipapers/999/

Gillespie, P. D. (2003). Agricultural trends in the Sydney region 1996-2001 census comparisons. Sydney: NSW Agriculture.

Goldman, R. (2010). Ecosystem services: how people benefit from nature. Environment, 52(5), 15-23. doi: $10.1080 / 00139157.2010 .507140$

Gosnell, H., \& Abrams, J. (2011). Amenity migration: Diverse conceptualizations of drivers, socioeconomic dimensions, and emerging challenges. GeoJournal, 76(4), 303-322. doi: 10.1007/s10708-009-9295-4 
Gosnell, H., Haggerty, J.H., \& Byorth, P. (2007). Ranch ownership change and new approaches to water resource management in Southwestern Montana: Implications for fisheries. Journal of the American Water Resources Association, 43(4), 990- 1003. doi: 10.1111/j.1752-1688.2007.00081.x

Gosnell, H., Haggerty, J. H., \& Travis, W.R. (2006). Ranchland ownership change in the Greater Yellowstone Ecosystem, 1990-2001: Implications for conservation. Society and Natural Resources, 19(8), 743-758. doi: 10.1080/08941920600801181

Goulden, M., Adger, W.N., Allison, E.H., Conway, D. (2013). Limits to resilience from livelihood diversification and social capital in lake social-ecological systems. Annals of the Association of American Geographers, 103(4), 906-924. doi:

$10.1080 / 00045608.2013 .765771$

Graham, S. (2013). Three cooperative pathways to solving a collective weed management problem. Australasian Journal of Environmental Management, 20(2), 116-129. doi: $10.1080 / 14486563.2013 .774681$

Guagnano, G.A., Stern, P.C., \& Dietz, T. (1995). Influences on attitude-behavior relationships: A natural experiment with curbside recycling. Environment and Behavior, 27, 699-71. doi: $10.1177 / 0013916595275005$

Haggerty, J.H., \& Travis, W.R. (2006). Out of administrative control: Absentee owners, resident elk and the shifting nature of wildlife management in southwestern Montana. Geoforum, 37(5), 816-830. doi: 10.1016/j.geoforum.2005.12.004

Hall, M. (2003). Editorial: The native, naturalized, and exotic—plants and animals in Human History. Landscape Research, 28(1), 5-9. doi: 10.1080/01426390306534 
Halseth G. (1998). Cottage country in transition: A social geography of change and contention in the rural recreational countryside. Montréal: McGill-Queen’s University Press.

Hay, I. (Ed). (2010). Qualitative research methods in human geography. Oxford: Oxford University Press.

Head, L., \& Atchison, J. (2009). Cultural ecology: Emerging human-plant geographies. Progress in Human Geography, 33(2), 236-245. doi: 10.1177/0309132508094075

Head, L. (2000). Cultural landscapes and environmental change. London: Oxford University Press.

Hindle, J.P., Nott, M.J., \& Crichton, J.R. (1987). Illawarra region—agricultural land classification study. Sydney: Department of Agriculture New South Wales.

Holmes, J. (2005). Impulses towards a multifunctional transition in rural Australia: Gaps in the research agenda. Journal of Rural Studies, 22, 142-160. doi:10.1016/j.jrurstud. 2005.08.006

Hoogesteger, J. (2013). Trans-forming social capital around water: Water user organizations, water rights, and nongovernmental organizations in Cangahua, the Ecuadorian Andes. Society and Natural Resources: An International Journal, 26,60-74. doi: $10.1080 / 08941920.2012 .689933$

Houston, P. (2005). Re-valuing the fringe: Some findings on the value of agricultural production in Australia's peri-urban regions. Geographical Research, 43(2), 209-223. doi: 10.1111/j. 1745-5871.2005.00314.x

Howard, J. (2008). The future of the Murray River: Amenity re-considered? Geographical Research 46(3), 291-302. doi: 10.1111/j.1745-5871.2008.00524.x 
Ikutegbe, V., Gill, N., Klepeis, P. (2014). Same but different: Sources of natural resource management advice for lifestyle oriented rural landholders. Journal of Environment Planning and Management, 58(9), 1530-1543. doi: 10.1080/09640568.2014.936551

Kasperson, R.E., Golding, D., Kasperson, J.X. (1999). Trust, risk, and democratic theory. In Cvetkovich, G., Lofstedt, R. (Eds.), Social Trust and the Management of Risk (pp. 22-

44). London: Earthscan.

Kiama Municipal Council. (2013). Kiama Municipal Council - Annual Report 2011-2012. Retrieved from http://www.kiama.nsw.gov.au/Your-Council/Major-Publications---

\section{Reports Kiama Municipal Council. (2013). Environment. Retrieved from}

http://ww.kiama.nsw.gov.au/environment/environment-landing

Kiama Municipal Council. (2014). Flora and Fauna. Retrieved from

http://www.kiama.nsw.gov.au/environment/our-environment/biodiversity/flora---fauna

Klepeis, P., Scull, P., Lalonde, T., Svajlenka, N., \& Gill, N. (2013). Changing forest recovery dynamics in the Northeastern United States. Area, 45(2), 239-248. doi: 10.1111/area. 12016

Klepeis, P., Gill, N., \& Chisholm, L.A. (2009). Emerging amenity landscapes: Invasive weeds and land subdivision in rural Australia. Land Use Policy, 26(2), 380-392. doi:10.1016/ j.landusepol.2008.04.006

Klinenberg, E. (20023). Heat wave: A social autopsy of disaster in Chicago. Chicago: University of Chicago Press.

Larsen S., Hutton, C. (2012). Community discourse and the emerging amenity landscapes of the rural American West. GeoJournal 77(5), 651-665. doi: 10.1007/s10708-011-9410-1

\section{Comment [6]:}

there is only one in-text citation referring to a Kiama Municipal Council, 2013. Which one is it: the Annual Report or the Environment? Delete whichever reference entry is not referred to in-text. 
Larsen, S.C., Foulkes, M., Sorenson, C., \& Thompson, A. (2011). Environmental learning and the social construction of an exurban landscape in Fremont County, Colorado. Geoforum, 42(1), 83-93. doi:10.1016/j.geoforum.2010.10.003

MacNaghten, P., \& Urry, J. (1998). Contested natures. London: Sage Publications.

Maestas, J.D., Knight, R.L., \& Gilgert, W.C. (2003). Biodiversity across a rural land-use gradient. Conservation Biology, 17(5), 1425-1434. doi: 10.1046/j. 1523-1739.2003.02371.x

Matarrita-Cascante, D., Stocks, G. (2013). Amenity migration to the global south: Implications for community development. Geoforum 49: 91-102. doi:10.1016/j.geoforum.2013.06.004

McNeely, J.A. (2004). Strangers in our midst: The problem of invasive species. Environment, 46(6), 17-30. doi: 10.1080/00139157.2004.10545159

Meadows, J., Herbohn, J., \& Emtage, N. (2012). Supporting cooperative forest management among small-acreage lifestyle landowners in Southeast Queensland, Australia. Society and Natural Resources: An International Journal, 26(7),745-761. doi: $10.1080 / 08941920.2012 .719586$

Mendham, E., Curtis, A., \& Millar, J. (2012). The natural resource management implications of rural property turnover. Ecology and Society, 17(4), 5. doi:10.5751/ES-05071-170405

Michelmore, M. (2003). The serrated tussock managers’ factpack. The State of New South Wales: $\quad$ NSW Agriculture.

Mills, K., \& Associates. (2006). The natural vegetation in the municipality of Kiama New South Wales_Final Report. Kiama: Report Prepared for Kiama Municipal Council. 
Mooney, H.A., Cleland, E.E. (2001). The evolutionary impact of invasive species. Proceedings of the National Academy of Sciences of the USA, 98(10), 5446-5451. doi: 10.1073/pnas. 091093398

Moss, L.A.G. (Ed.) (2006). The amenity migrants: Seeking and sustaining mountains and their cultures. Cambridge, MA: CABI Publishing.

Polce, C., Kunin, W.E., Biesmeijer, J.C., Dauber, J., Phillips, O.L., \& the ALARM Field Site Network (2011). Alien and native plants show contrasting responses to climate and land use in Europe. Global Ecology and Biogeography, 20(3), 367-379. doi:10.1111/j.14668238.2010.00619.x

Pretty, J., Ward, H. (2001). Social capital and environment. World Development, 29(2), 209-227. doi:10.1016/S0305-750X(00)00098-X

Putnam, R. (1995). Bowling alone: America's declining social capital. Journal of Democracy 6(1), 65-78.

Robbins, P. (2004). Comparing invasive networks: Cultural and political biographies of invasive species. The Geographical Review, 94(2), 139-156. doi: 10.1111/j. 19310846.2004.tb00164.x

Robbins, P. (2007). Lawn people: How grasses, weeds, and chemicals make us who we are. Philadelphia: Temple University Press.

Seidl, D., \& Klepeis, P. (2011). Human dimensions of earthworm invasion in the adirondack state park. Human Ecology, 39(5), 641-655. doi: 10.1007/s10745-011-9422-y

Sobels, J., Curtis, A., Lockie, S. (2001). The role of landcare networks in rural Australia: Exploring the contribution of social capital. Journal of Rural Studies, 17(3), 265-276. doi:10.1016/S0743-0167(01)00003-1 
Sorice, M.G., Kreuter, U.P., Wilcox, B.P., Fox, W.E. III. (2014). Changing landowners, changing ecosystem? Land-ownership motivations as drivers of land management practices. Journal of Environmental Management, 133, 144-152. doi:10.1016/j.jenvman. 2013.11.029

Tidwell, L.S., Brunson, M.W. (2008). Volunteering to manage rangeland weeds. Rangelands, 30(4), 19-24. doi:10.2111/1551-501X(2008)30[19:VTMRW]2.0.CO;2

Vitousek, P.M., Dantonio, C.M., Loope, L.L., Rejmanek, M., Westbrooks, R. (1997). Introduced species: A significant component of human caused global change. New Zealand Journal of Ecology, 21(1), 1-16.

Wagner, M.W., Kreuter, U.P., Kaiser, R.A., \& Wilkins, R.N. (2007). Collective action and social capital of wildlife management associations. Journal of Wildlife Management,

71(5), $\quad$ 1729-1738. doi:10.2193/2006-199

Williams, J.A., \& West, C.J. (2000). Environmental weeds in Australia and New Zealand: Issues and approaches to management. Austral Ecology, 25(5), 425-444. doi:10.1046/j.14429993.2000.01081.x

Wilson, G. A. (2012). Community resilience and environmental transitions. New York: Routledge.

Wilson, G. A. (2007). Multifunctional agriculture: A transition theory perspective. Cambridge: CABI Publishing. 
